\title{
Dynamics of planktivory in a coastal area of the northern Baltic Sea
}

\author{
Lars G. Rudstam*, Sture Hansson, Sif Johansson, Ulf Larsson \\ Department of Systems Ecology and Department of Zoology, University of Stockholm, S-106 91 Stockholm, Sweden
}

\begin{abstract}
We studied the seasonal dynamics of zooplanktivory by the major zooplanktivores (sprat Sprattus sprattus, herring Clupea harengus and the mysid shrimp Mysis mixta) in 3 coastal areas of the northern Baltic Sea proper from the beginning of July through the end of October, 1985. The 3 areas are within $30 \mathrm{~km}$ of each other and differ in nutrient loading and primary productivity. Consumption rates were obtained by combining abundance estimates of the planktivores (from Bongo nets, gill nets and acoustics) with diet analysis and bioenergetics models. Both the dominating planktivore groups and total planktivory rates changed over the study period. Sprat and yearling herring were the major zooplanktivores in July and August whereas young-of-year herring and $M$. mixta were more important in September and October. Planktivory rates increased from low levels at the beginning of July to a peak in August coinciding with a late summer decline in crustacean zooplankton biomass. Planktivory rates were lower than estimated zooplankton production rates in July and early Al:gust when zooplankton biomass was increasing and similar to or higher than production in the autumn when zooplankton biomass declined. Both clupeids and mysids consistently selected prey in the order cladocerans (Bosmina longispina maritima and Pleopis polyphemoides) $>$ Eurytemora affinis hirundoides copepods $>$ Acartia copepods. The selected species represented a smaller proportion of total zooplankton biomass and decreased earlier in the season in the least productive area, indicating a larger and earlier effect of planktivory in that area compared to the most productive area.
\end{abstract}

\section{INTRODUCTION}

It is well established that fish and invertebrate predators affect the species composition and size structure of zooplankton in lakes (Hrbacek et al. 1961, Brooks \& Dodson 1965, Dodson 1974). Planktivores may also indirectly affect phytoplankton and primary production (Carpenter et al. 1985). Although such top-down regulation has been given less attention in marine and estuarine environments, several authors have suggested that predation from invertebrates regulates seasonal zooplankton cycles and causes changes in zooplankton species composition (Möller 1979, Lonsdale 1981, Deason \& Smayda 1982, Davis 1984, Ohman 1986, Horsted et al. 1988, Roff et al. 1988, Suthers \& Frank 1990; but see Kuipers et al. 1990). Fish are generally not considered important zooplankton predators in oceanic and coastal areas (but see Landry 1978, Fulton 1985, Kimmerer \& McKinnon 1989, Hansson et al. 1990a). However, fish yield per unit of primary production is higher in coastal areas, including the

\footnotetext{
- Present address: Center for Limnology, University of Wisconsin, Madison, Wisconsin 53705, USA
}

Baltic Sea, than in lakes (Nixon 1982), and there is therefore no reason to expect weaker top-down effects of planktivorous fish in coastal marine environments than in freshwater.

In this paper we analyze the dynamics of zooplanktivory by both fish and invertebrates in 3 coastal areas of the northern Baltic proper from the beginning of July through the end of October, 1985. The 3 study areas are all within $30 \mathrm{~km}$ of the Askö field station on the east coast of Sweden but differ in nutrient loading, primary production and summer chlorophyll levels. We combined abundance estimates from field samples with diet analyses and bioenergetics models to create an integrated picture of the changes in zooplanktivory over time in the 3 areas. Seasonal patterns of planktivory are then compared with the seasonal development of zooplankton abundance and species composition. Specifically we will address the following questions: (1) Which predators are the dominating planktivores and do they change spatially and seasonally? (2) Are there seasonal changes in planktivory that correlate with seasonal changes in zooplankton abundances? (3) Are differences in zooplankton community structure among the 3 study areas predictable from differences in planktivory? 


\section{METHODS AND MATERIALS}

Study area. The differences in nutrient loading between the 3 areas are the result of nutrient discharge from a municipal sewage treatment plant in the inner part of Himmerfjärd Bay (Fig. 1). The 3 areas were the inner basin of this bay (Inner Bay), an outer basin of the same bay (Outer Bay) and a nearby reference area (Askö area) which is not measurably affected by the nutrient discharge. Water circulation in the Bay is driven by winds and freshwater runoff as the Baltic lacks tides (Wilmot et al. 1985). The zooplankton seasonal dynamics has been studied in these areas since 1977 as part of a research project on eutrophication in the Baltic Sea (Elmgren \& Larsson 1987). In this project, nutrients $(\mathrm{N}$ and $\mathrm{P})$, oxygen, salinity, temperature, chlorophyll $a$, and phytoplankton primary production have been measured (Table 1). The higher nutrient levels in the Bay are associated with 50 to $100 \%$ higher annual primary production than in the Askö area. Estimated annual zooplankton production is also on average about $100 \%$ higher in the Bay, primarily due to higher production of cladocerans (Bosmina longispina maritima E. Müller and Pleopsis polyphemoides Leuckart) and rotifers. The copepods are dominated by Eurytemora affinis hirundoides (Nordquist) in the Bay and by Acartia spp. in the Askö area. This shift in species dominance has been observed in all years studied (1977 to 1988). Our previous experience suggests that herring Clupea harengus and the mysid shrimp Mysis mixta (Liljeborg) are the most important planktivores and that estimates of planktivory are high compared with estimates of zooplankton production (Aneer 1980, Rudstam et al. 1986, Hansson et al. 1990a).

Field sampling and sample processing. Zooplankton larger than $90 \mu \mathrm{m}$ were sampled during the day at every $5 \mathrm{~m}$ depth from surface to bottom with a $1.5 \mathrm{~m}$ high closable zooplankton trap (volume $25.8 \mathrm{l}$ ), pooled over the whole water column, and preserved in $4 \%$ disodium-tetraborate buffered formaldehyde. Total volume sampled varied between 130 I (Inner Bay, Stn 5) and 2051 (Outer Bay). A similar plankton trap was found to be more efficient than traditional vertical net tows (WP-2 net) for plankton in the Baltic (Kankaala 1984). Samples were taken at $2 \mathrm{wk}$ intervals at Stns 1 (Askö area) and 4 (Inner Bay) with the exception of the middle of August (equipment problem), and monthly at Stns 3 (Outer Bay) and 5 (Inner Bay). At least a quarter of the sample or 400 specimens were counted and identified to species (stage for copepods), and converted to biomass (Table 2).

Mysids and fish larvae were sampled in the water column at night on 5 occasions from July 3 to October 24 in the Outer Bay and the Askö area using oblique Bongo net tows. Bottom depth varied between 28 and

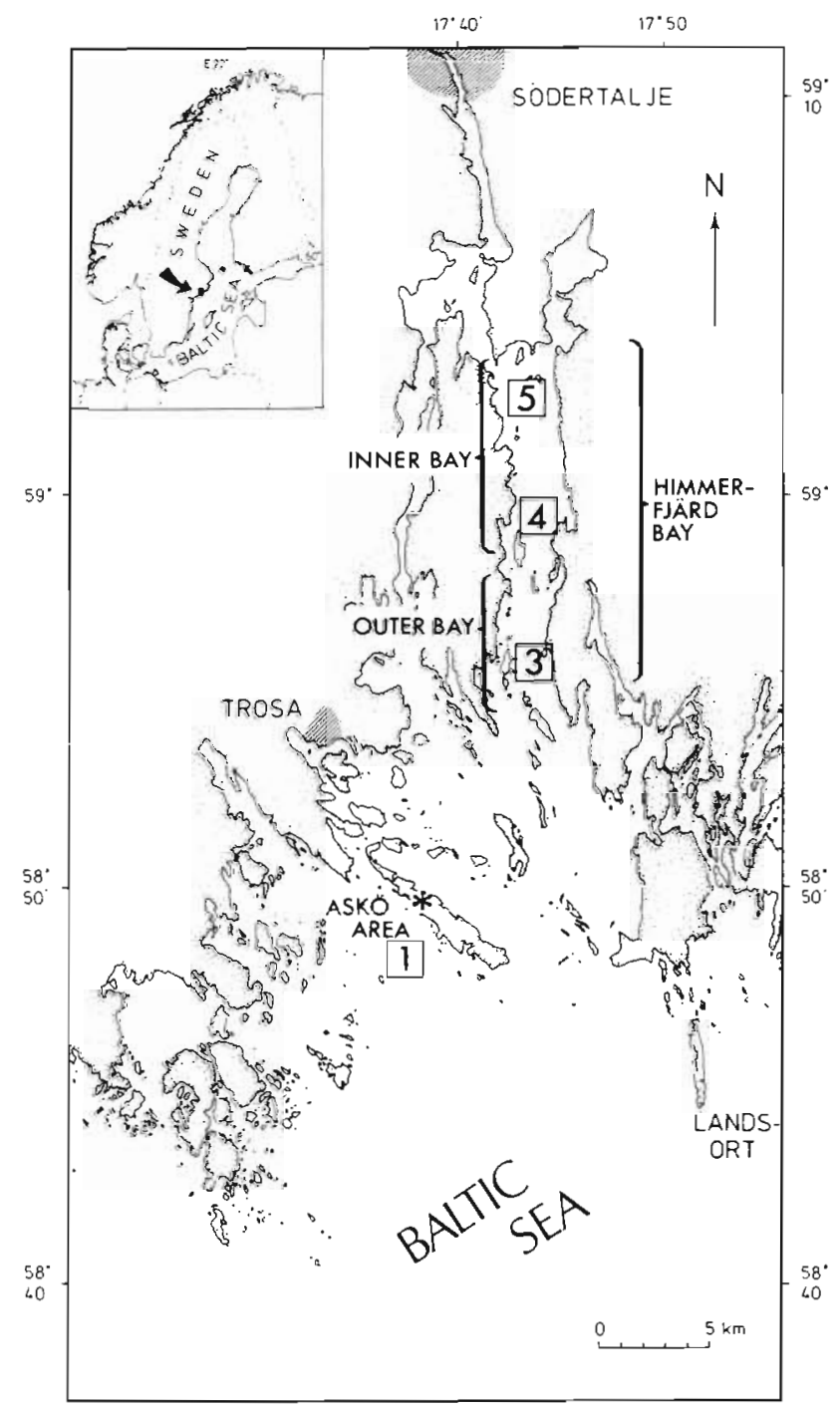

Fig. 1. Study area. Sampling stations for collections of zooplankton and of water for chemical analysis are indicated with a numbered symbol. Station numbers are identical to those used in other publications concerning this area. More detailed maps with acoustic and Bongo net transects can be found in Hansson et al. (1987) and Rudstam et al. (1986)

$36 \mathrm{~m}$. Duplicate samples were collected except in early July in both areas and at the beginning of August in the Askö area. Nocturnal sampling was necessary because mysids occur in the water column only at night (Rudstam et al. 1989a). Samples were preserved in $4 \%$ buffered formaldehyde and all animals (excluding copepods and cladocerans) were counted. Total length of up to 20 clupeid larvae and mysid shrimps per sample was measured to the nearest $\mathrm{mm}$ and converted to biomass (Table 2). We did not identify clupeid larvae to species.

The pelagic fish populations were sampled in all 3 areas with five $3 \mathrm{~m}$ wide and $30 \mathrm{~m}$ deep monofilament 
Table 1. Relevant environmental and biological data based on samples at ca 2 wk intervals during 1985 (from Larsson 1986, Larsson et al. 1991). The surface layer is the depths 0 to $20 \mathrm{~m}$ in the Askö area and 0 to $10 \mathrm{~m}$ in the Bay. The bottom layer is the depths from $20 \mathrm{~m}$ to the bottom in the Asko area and from $10 \mathrm{~m}$ to the bottom in the Bay. Oxygen concentrations at the bottom in 1985 was above $6 \mathrm{mg} \mathrm{l}^{-1}$ in all areas. All years between 1977 and 1988 are included in the long-term averages for chlorophyll and primary production. All years except 1986 are included for zooplankton production for the Asko area and the Inner Bay and the years 1977, 1978 1985-88 for the Outer Bay. The chiorophyll $a$ values represent the average for samples taken between March 1 and November 30 . Range of chlorophyll values observed between July 1 and October 30,1985, are also included

\begin{tabular}{|c|c|c|c|}
\hline & Askö & Outer Bay & Inner Bay \\
\hline Water depth (m) & 35 & 40 & 27 \\
\hline \multicolumn{4}{|c|}{ Mean temperature (May-October, ${ }^{\circ} \mathrm{C}$ ) } \\
\hline Surface layer & 9.3 & 11.7 & 12.0 \\
\hline Bottom layer & 5.0 & 6.0 & 7.2 \\
\hline \multicolumn{4}{|c|}{ Mean salinity (May-October, \%o) } \\
\hline Surface layer & 6.4 & 6.0 & 5.7 \\
\hline $20-30 \mathrm{~m}$ depth & 6.8 & 6.5 & 6.3 \\
\hline Winter total $\mathrm{N}\left(\mathrm{mg} \mathrm{m}^{-3}\right)$ & 315 & 400 & 475 \\
\hline Winter total $\mathrm{P}\left(\mathrm{mg} \mathrm{m}^{-3}\right)$ & 30 & 36 & 38 \\
\hline \multicolumn{4}{|c|}{ Chlorophyll a (mg chl m$\left.{ }^{-2}\right)$} \\
\hline Average 1985 & 26 & 46 & 73 \\
\hline Range 1985 & $12-45$ & $33-77$ & $33-113$ \\
\hline Average $1977-88$ & 37 & 68 & 82 \\
\hline Range & $28-49$ & $32-78$ & $58-104$ \\
\hline \multicolumn{4}{|c|}{ Primary production $\left(\mathrm{gC}^{-2} \mathrm{yr}^{-1}\right)$} \\
\hline $1985^{\circ}$ & 126 & 195 & 198 \\
\hline Average $1977-87$ & 129 & 215 & 206 \\
\hline Range & $97-161$ & $165-286$ & $150-278$ \\
\hline \multicolumn{4}{|c|}{ Zooplankton production $\left(\mathrm{gC}^{-2} \mathrm{yr}^{-1}\right)$} \\
\hline 1985 Jun $15-$ Nov 15 & 1.7 & 8.6 & 5.0 \\
\hline 1985 whole year & 2.0 & - & 7.4 \\
\hline Average $1977-88$ & 6.4 & - & 11.7 \\
\hline Range & $2.0-9.7$ & & $7.4-16.2$ \\
\hline
\end{tabular}

vertical gill nets (Hansson 1988; mesh sizes 16, 24, 30, 33.2 , and $37.6 \mathrm{~mm}$ stretch mesh). The nets were set at dusk in 28 to $30 \mathrm{~m}$ deep water and lifted 5 to $6 \mathrm{~h}$ later.
Fish were identified to species, measured and weight calculated from weight-length regressions (Table 2). Fish used for diet analysis were frozen within 1 to $3 \mathrm{~h}$ after lifting the nets. Catches were corrected for size selectivity of the nets (Rudstam et al. 1988).

Acoustic data from a $70 \mathrm{kHz}$ single-beam echosounder (Simrad EY/M, half power beam width $11.2^{\circ}$, pulse length $0.6 \mathrm{~ms}$, TVG of $40 \log R$ ) were recorded on cassette tapes at a ship speed of 1.5 to $2 \mathrm{~m} \mathrm{~s}^{-1}$ at night when the fish were dispersed in the water column. Recordings were made for ca $40 \mathrm{~min}$ in the Askö area and in the Outer Bay and for $80 \mathrm{~min}$ in the Inner Bay. The same transects were used on each sampling occasion. Tapes were analyzed using an echo processor (Powell \& Stanton 1983) and the deconvolution method (Rudstam et al. 1987). The proportion of fish in a limited number of size groups can be extracted from the echo peak distributions when fish size groups are sufficiently distinct, but this was not possible for all sampling occasions (Rudstam 1988). To be consistent, we used the proportions of different fish species and size groups in gill net catches to calculate abundances of different fish groups from total acoustic abundances. At low fish densities, acoustics and gill nets samples yielded similar size distributions (Rudstam et al. 1988, 1989b). We consider only targets larger than $-56 \mathrm{~dB}$ (Fish larger than ca $5 \mathrm{~cm}$; Rudstam et al. 1988) due to low signal-to-noise ratios for smaller fish sizes.

Zooplankton production. Species-specific zooplankton daily production was calculated from biomass estimates and temperature-dependent growth equations (Table 2). Egg production from adult females was assumed equal to specific somatic production of Copepodite V (Kiørboe et al. 1985) and adult males were assumed not to contribute to production. We used the mean temperature between surface and bottom for copepods and the mean temperature above the thermocline for copepod nauplii, cladocerans and rotifers (based on previous studies on diel vertical migrations in this area; Hansson et al. 1990a). Production

Table 2. Literature used for calculating biomass, energy density, production (prey) and consumption (predators)

\begin{tabular}{|lll|}
\hline Taxon & \multicolumn{1}{c|}{ Biomass } & Production/consumption \\
\hline Prey & & \\
Eurytemora & Hernoth (1985) & Vuorinen (1982) \\
Other copepods & Hernroth (1985) & McLaren (1978) \\
Cladocerans & Hernroth (1985) & Kankaala et al. (1984) \\
Rotifers & Hernroth (1985) & Pourriot \& Deluzarches (1971) \\
Predators & Rudstam et al. (1989b) & \\
Herring and sprat & Checkley (1984) & Rudstam (1989a) \\
Clupeid larvae & Rudstam (1989b), Wiktor \& Szaniawska (1989) & Rudstam (1989b) \\
Mysis mixta & & \\
\hline
\end{tabular}


over the whole study period was obtained by linear interpolation between sampling dates (Kimmerer 1987). These production estimates do not account for differences in food availability between our study areas (see 'Discussion').

Diet analysis. Zooplankton parts (mandibles and second antennae) in Mysis mixta stomachs were identified and counted under 100 to $160 \times$ magnifications (see Rudstam et al. 1989a). Between 5 to $25 \%$ of the copepod mandibles could not be identified and were assigned to species in the same proportion as those identified. Stomach contents of sprat and 3 size groups of herring (young-of-year [YOY], yearling, and older fish) were first investigated under low magnification and the proportion by volume of major prey groups (zooplankton, mysids, fish, and insects) estimated. Up to 100 individual zooplankton prey per stomach were then identified and counted under an inverted microscope using whole zooplankton, tail ends and head capsules of cladocerans and furca of copepods. Due to taxonomic difficulties, the copepods were grouped as Eurytemora/Temora or as other species (primarily Acartia spp.).

Proportions of different zooplankton in mysid and fish diets were calculated as the average of the proportions by number (for selectivity calculations) and by weight (for calculations of consumption rates) in individual stomachs (excluding stomachs with less than 5 identified prey items). Numbers were converted to wet weight assuming a weight of $20 \mu \mathrm{g}$ for copepods, $10 \mu \mathrm{g}$ for cladocerans, $1 \mu \mathrm{g}$ for nauplii, $0.2 \mu \mathrm{g}$ for rotifers and $0.02 \mu \mathrm{g}$ for tintinnids (from Hernroth 1985).

Consumption rates. Zooplanktivory by clupeid larvae was calculated from maximum growth rates observed in the laboratory and experimentally derived relationships between growth and ingestion for Baltic herring (Kiørboe \& Munk 1986). We consider this relationship to represent upper bounds for larval consumption. For older fish and mysids, we used bioenergetics models developed by Rudstam (1989a, 1989b) and the computer program by Hewett \& Johnson (1987). These models calculate food consumption from observed growth, occupied temperatures and the energy density of prey and predator. We used monthly weight changes to estimate consumption for young herring, sprat and Mysis mixta. Since we could not follow growth of individual age classes of older herring, we used a specific consumption rate for older herring derived from an annual growth period (Rudstam 1989a). For modeling purposes we consider sprat to be a yearling herring. The thermal histories of clupeids and mysids were obtained from the vertical distributions observed in gill nets, acoustics and Bongo nets (Rudstam 1988, Rudstam et al. 1989a). Energy density of the predators were assumed to vary seasonally between 5120 and $5940 \mathrm{~J}$ $\mathrm{g}^{-1}$ wet wt for herring (Aneer 1975) and to increase from $3230 \mathrm{~J} \mathrm{~g}^{-1}$ wet wt in juvenile mysids to $3720 \mathrm{~J} \mathrm{~g}^{-1}$ wet wt in adult mysids (Wiktor \& Szaniawska 1989). Prey were assumed to have a constant energy density of $2850 \mathrm{~J} \mathrm{~g}^{-1}$ wet wt (Laurence 1976, Vijverberg \& Frank 1976). These models yield consumption rates in wet weight. Individual perturbation of the parameters in the models with $\pm 10 \%$ of their nominal value resulted in at most a similar change in predicted daily consumption rates.
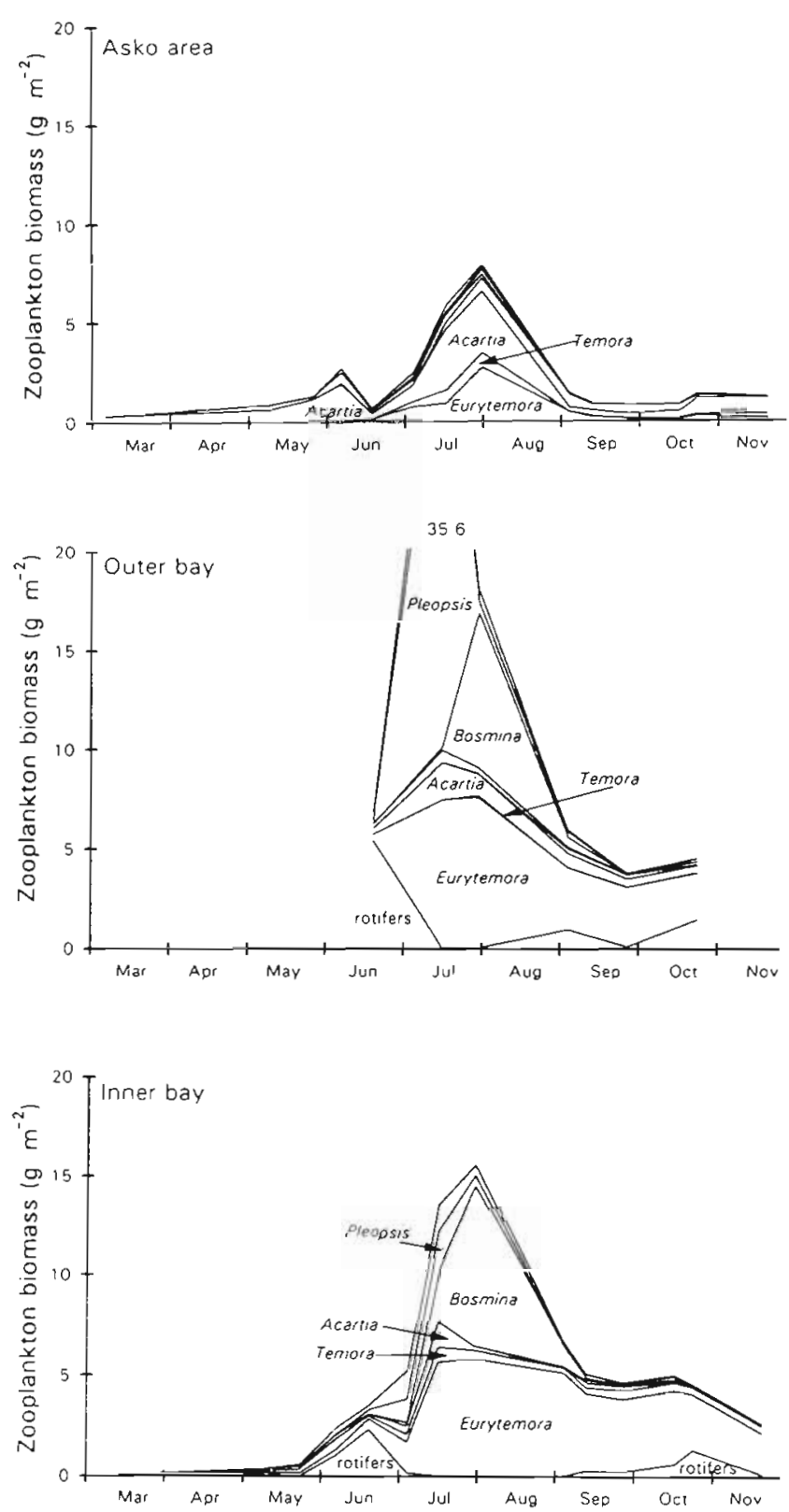

Fig. 2. Seasonal development of zooplankton biomass in 1985 in the Inner Bay (average of Stns 4 \& 5), in the Outer Bay (Stn 3) and in the Asko area (Stn 1). Total biomass is divided in the major taxonomic groups discussed in the paper 


\section{RESULTS}

\section{Distribution and abundance}

Zooplankton. The increase in zooplankton biomass during the summer was primarily caused by an increase of the copepods Eurytemora and Acartia spp. in the Asko area and of Eurytemora and cladocerans (Bosmina longispina maritima and Pleopsis polyphemoides) in the Bay (Fig. 2). Soft-bodied rotifers of the genus Synchaeta were common in early spring and late autumn in the Bay. There was a general decline in zooplankton biomass in late summer. The seasonal development and species composition in the different areas were similar to observations from 1977 to 1988 (Johansson 1983, Larsson et al. 1991). Annual production was low in 1985 compared to other years, especially in the Askö area, due primarily to low abundances of cladocerans and rotifers (Table 1).

Macro-invertebrates. Mysids were the dominating group in Bongo net samples. They constituted 58 to $96 \%$ of the catch by number, except in the early July samples when few mysids and comparatively large numbers of clupeid larvae and of the normally benthic amphipod Pontoporeia spp. were caught. The dominant mysid was Mysis mixta which increased in water column abundances over the summer (Table 3). Small Neomysis integer (Leach) (5 to $7 \mathrm{~mm}$ ) were also common in the Bay in August and September (20 to 60 ind. $\left.\mathrm{m}^{-2}\right) . M$. mixta produces one generation per year which is released in the spring and growth of the juveniles can be followed throughout the year (Rudstam \& Hansson 1990). Their growth was faster in the Bay than in the Askö area (Table 4; Hansson et al. 1990b).

Table 4. Length (mm) of planktivores in 1985. Mysis mixta and clupeid larvae were caught with Bongo nets. Sprat and 3 size classes of herring are from gill net samples corrected for the size selectivity of the nets (see Rudstam et al. 1988)

\begin{tabular}{|c|c|c|c|c|c|c|}
\hline Date & $\begin{array}{c}\text { Mysis } \\
\text { mixta } \\
\text { juveniles }\end{array}$ & $\begin{array}{l}\text { Clupeid } \\
\text { larvae }\end{array}$ & YOY & $\begin{array}{l}\text { Herring } \\
\text { Age It }\end{array}$ & Older & Sprat \\
\hline \multicolumn{7}{|c|}{ Askö area (Stn 1) } \\
\hline Jul 4 & 8.6 & 8.2 & NA & 95 & 234 & 95 \\
\hline Aug 1 & 11.2 & 15.4 & NA & 113 & 188 & 97 \\
\hline Aug 28 & 13.6 & 12.5 & 82 & 121 & 223 & 106 \\
\hline Sep 24 & 16.2 & NA & 89 & 125 & 209 & 98 \\
\hline Oct 23 & 16.4 & 12.8 & 88 & NA & 202 & 125 \\
\hline \multicolumn{7}{|c|}{ Outer Bay (Stn 3) } \\
\hline Jul 4 & 8.3 & 11.7 & NA & 85 & 187 & 85 \\
\hline Aug 1 & 12.1 & 16.5 & $30^{\alpha}$ & 115 & 183 & 96 \\
\hline Aug 28 & 15.3 & 17.8 & $70 / 37^{a}$ & 128 & 168 & 116 \\
\hline Sep 24 & 17.9 & 22.1 & $76 / 65^{a}$ & NA & 190 & 111 \\
\hline Oct 23 & 18.6 & 19.0 & $76 / 67^{a}$ & 135 & 185 & $131 / 60^{b}$ \\
\hline \multicolumn{7}{|c|}{ Inner Bay (Stn 5) } \\
\hline Jul 4 & $\mathrm{NA}$ & $\mathrm{NA}$ & $\mathrm{NA}$ & 88 & 183 & 102 \\
\hline Aug 1 & $\mathrm{NA}$ & $\mathrm{NA}$ & $\mathrm{NA}$ & 117 & 193 & 98 \\
\hline Aug 28 & $\mathrm{NA}$ & $\mathrm{NA}$ & 66 & 128 & 165 & 107 \\
\hline Sep 24 & $\mathrm{NA}$ & NA & 74 & 131 & 174 & $\mathrm{NA}$ \\
\hline Oct 23 & $\mathrm{NA}$ & $\mathrm{NA}$ & 76 & 131 & 181 & 115 \\
\hline
\end{tabular}

Table 3. Seasonal changes in abundance (ind. $\mathrm{m}^{-2}$ ) of $M y$ sis mixta, sprat Sprattus sprattus and 3 size classes of herring Clupea harengus in the 3 study areas in 1985. Abundances are from Bongo net catches (mysids and clupeid larvae at Stns 1 and 3) and from a combination of acoustics and gill net samples for metamorphosed fish (see text). The range of abundances from duplicate Bongo tows are in parenthesis. NA: not available

\begin{tabular}{|c|c|c|c|c|c|c|c|c|}
\hline Date & $\begin{array}{l}\text { Mysis } \\
\text { mixta }\end{array}$ & & $\begin{array}{l}\text { Clupeid } \\
\text { larvae }\end{array}$ & & YOY & $\begin{array}{l}\text { Herring } \\
\text { Age I+ }\end{array}$ & Older & Sprat \\
\hline \multicolumn{9}{|c|}{ Askö area (Stn 1) } \\
\hline Jul 4 & 5 & & 7 & & & 0.001 & 0.046 & 0.002 \\
\hline Aug 1 & 28 & & 5 & & & 0.051 & 0.013 & 0.032 \\
\hline Aug 28 & 47 & $(44-51)$ & 0.3 & $(0.2-0.5)$ & 0.042 & 0.087 & 0.016 & 0.087 \\
\hline Sep 24 & 65 & $(44-85)$ & 0.1 & $(0-0.1)$ & 0.070 & 0.019 & 0.013 & 0.012 \\
\hline Oct 23 & 76 & $(66-72)$ & 0.3 & $(0.2-0.4)$ & 0.032 & 0 & 0.071 & 0.063 \\
\hline \multicolumn{9}{|c|}{ Outer Bay (Stn 3) } \\
\hline Jul 4 & 2 & & 4 & & & 0.002 & 0.039 & 0.001 \\
\hline Aug 1 & 18 & $(17-18)$ & 9 & $(9-9)$ & & 0.078 & 0.011 & 0.093 \\
\hline Aug 28 & 28 & $(27-29)$ & 2 & $(2-2)$ & 0.514 & 0.176 & 0.062 & 0.031 \\
\hline Sep 24 & 30 & $(25-34)$ & 0.4 & $(0.3-0.5)$ & 0.659 & 0.003 & 0.020 & 0.070 \\
\hline Oct 23 & 16 & $(12-20)$ & 0.1 & $(0.1-0.2)$ & 0.779 & 0.058 & 0.117 & 0.020 \\
\hline \multicolumn{9}{|c|}{ Inner Bay (Stns $4 \& 5$ ) } \\
\hline Jul 4 & NA & & NA & & & 0.004 & 0.073 & 0.031 \\
\hline Aug 1 & NA & & NA & & & 0.319 & 0.076 & 0.383 \\
\hline Aug 28 & NA & & NA & & 1.21 & 0.136 & 0.072 & 0.755 \\
\hline Sep 24 & NA & & NA & & 2.00 & 0.055 & 0.034 & 0 \\
\hline Oct 23 & NA & & NA & & 1.54 & 0.117 & 0.160 & 0.017 \\
\hline
\end{tabular}


Fish larvae. Clupeid larvae occurred primarily in the July 4, August 1 and August 28 samples and reached abundances of 9 ind. $\mathrm{m}^{-2}$ (Table 3 ). Herring spawn primarily in June in this area, but newly hatched clupeid larvae were found throughout the summer because sprat (which spawn in the open Baltic in the summer) or later-hatched herring recruited to the larval populations (Aneer 1985). Other fish larvae, primarily gobies, always numbered less than 1 ind. $\mathrm{m}^{-2}$.

Fish. Herring $(73 \%)$, sprat $(24 \%)$, smelt Osmerus eperlanus L. (2\%) and roach Rutilus rutilus L. (1\%) constituted over $99 \%$ of the fish caught in gill nets. Because of their dominance in gill net catches, we assumed that all acoustic targets were clupeids. Some smaller fish, primarily 2 to $3 \mathrm{~cm}$ sand goby Pomatoschistus minutus Pallas, were caught in the Bongo nets but these fish are too small to be included in the acoustic density estimates (Rudstam et al. 1988). YOY and juvenile herring can be separated using the length distributions of fish caught in gill nets and these distributions were used to calculate seasonal growth patterns for these age groups (Table 4). Sprat were probably of Age 1 and 2, but some YOY were caught in late October (Table 4). We expected the average length of YOY fish caught in the gill nets to be biased toward larger fish because of the mesh sizes used. Fish caught in gill nets were larger than fish caught in Bongo nets at the end of August, but differences were small in September and October (Table 3).

At both stations in the bay, hydroacoustic fish abundance increased from values around 0.05 fish $\mathrm{m}^{-2}$ at the beginning of July to between 0.7 and 1 fish $\mathrm{m}^{-2}$ in the Outer Bay and to between 1.5 and 2 fish $\mathrm{m}^{-2}$ in the Inner Bay in late August through October, primarily a result of increased abundances of YOY herring. The increase in the Askö area was smaller, resulting in an order of magnitude higher autumn abundances in the Bay (Table 3). Sprat and yearling herring were common in the 1 August samples. Abundances of older herring varied less with time and among sampling areas.

\section{Diet of major zooplanktivores}

Mysis mixta. We found 4 species of calanoid copepods, 2 species of cladocerans, rotifers (Keratella sp.) and tintinnids in $M$. mixta stomachs (Table 5). Stomach content of the mysids reflected prey availabil-

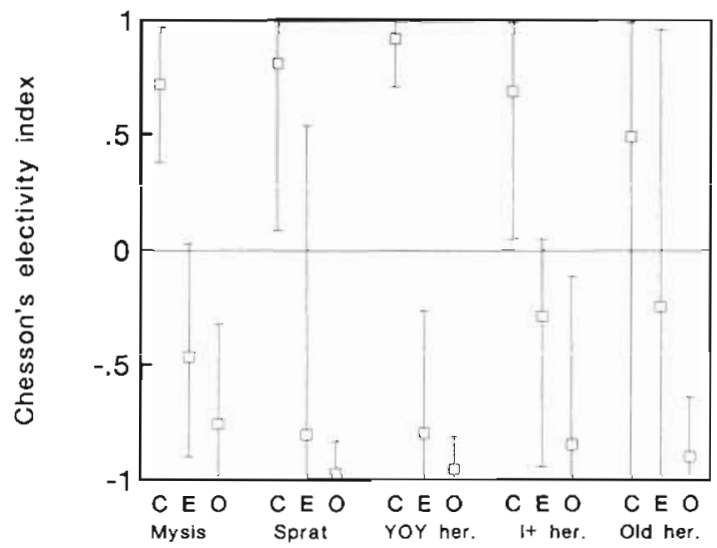

Fig. 3. Electivity indices (Chesson 1983) for the major planktivores between the end of July and the end of October for 3 prey groups: Cladocerans (C), copepodites and adults of Eurytemora/Temora $(\mathrm{E})$ and of other copepods $(\mathrm{O}$, primarily Acartia spp.). Electivities are based on zooplankton abundances in the whole water column. Symbol represent average values and line the range of values observed. Numbers of occasions included are 8 for Mysis, 10 for sprat, 8 for YOY herring, 9 for age I+ herring, and 13 for older herring

Table 5. Proportions by number (in \%) of different prey groups identified in stomachs of Mysis mixta caught in the water column between 10 and $30 \mathrm{~m}$ depth at night in 1985. Length of mysids (mm), number of stomachs analyzed (N), number of empty stomachs $(E)$ and total number of identified prey items are also given. Eur.: Eurytemora; Tem.: Temora; Aca.: Acartia; Pse.: Pseudocalanus; Bos.: Bosmina; Ple.: Pleopsis; Ker.: Keratella; Rot.: Rotatoria; Tint.: Tintinidae

\begin{tabular}{|c|c|c|c|c|c|c|c|c|c|c|c|c|c|c|}
\hline \multirow[t]{2}{*}{ Date } & \multirow[t]{2}{*}{ Stn } & \multicolumn{2}{|c|}{$\begin{array}{l}\text { Mysid } \\
\text { length }\end{array}$} & \multirow[t]{2}{*}{$N$} & \multirow[t]{2}{*}{ E } & \multirow{2}{*}{$\begin{array}{c}\text { No. of } \\
\text { identified } \\
\text { prey }\end{array}$} & \multicolumn{4}{|c|}{ Copepoda } & \multicolumn{2}{|c|}{ Cladocera } & \multirow{2}{*}{$\begin{array}{l}\text { Rot. } \\
\text { Ker }\end{array}$} & \multirow[t]{2}{*}{ Tint. } \\
\hline & & $\bar{x}$ & (SD) & & & & Eur & Tem. & Aca. & Pse. & Bos. & Ple. & & \\
\hline \multirow[t]{2}{*}{ Jul 4} & 1 & 6.7 & (1.9) & 9 & 6 & 3 & 100 & 0 & 0 & 0 & 0 & 0 & 0 & 0 \\
\hline & 3 & 7.1 & (1.1) & 8 & 0 & 13 & 56 & 0 & 3 & 0 & 0 & 37 & 4 & 0 \\
\hline \multirow[t]{2}{*}{ Aug 1} & 1 & 11.5 & $(2.0)$ & 15 & 0 & 142 & 32 & 1 & 8 & 0 & 6 & 42 & 5 & 4 \\
\hline & 3 & 12.3 & $(1.2)$ & 15 & 0 & 205 & 22 & 0 & 2 & 0 & 56 & 11 & 7 & 2 \\
\hline \multirow[t]{2}{*}{ Aug 28} & 1 & 13.6 & (1.1) & 15 & 1 & 335 & 19 & 2 & 9 & $<1$ & 13 & 10 & 7 & 40 \\
\hline & 3 & 15.6 & (1.4) & 15 & 0 & 234 & 34 & 0 & 7 & 0 & 26 & 2 & 21 & 10 \\
\hline \multirow[t]{2}{*}{ Sep 24} & 1 & 16.2 & $(0.6)$ & 10 & 0 & 161 & 26 & $<1$ & 12 & 4 & 12 & 6 & 19 & 21 \\
\hline & 3 & 16.9 & $(0.7)$ & 10 & 0 & 391 & 60 & $<1$ & 8 & 1 & 3 & $<1$ & 23 & 3 \\
\hline \multirow[t]{2}{*}{ Oct 23} & 1 & 14.5 & $(1.3)$ & 16 & 0 & 137 & 27 & 3 & 13 & 0 & 4 & 2 & 4 & 47 \\
\hline & 3 & 17.3 & (1.5) & 15 & 1 & 120 & 68 & 2 & 1 & 1 & 7 & $<1$ & 13 & 7 \\
\hline
\end{tabular}


Table 6. Estimated proportions of zooplankton in fish stomachs (\% by volume) and proportions of identified zooplankton taxa (\% by number). Proportions were calculated as the average of proportions in individual fish. Fish were caught in Bongo nets and gill nets at Stns 1,3 \& 5 in 1985 . Length of fish $(\mathrm{mm})$, number of stomachs analyzed $(\mathrm{N})$, number of empty stomachs (E) and the total number of identified prey items are also given. Prop.: proportion; zoopl.: zooplankton; id.: identified; ad\&cop.: adult and copepodites; E/T: Eurytemora/Temora; Unid.: unidentified; Bos.: Bosmina; Ple.. Pleopsis

\begin{tabular}{|c|c|c|c|c|c|c|c|c|c|c|c|c|c|}
\hline Date & Stn & \multicolumn{2}{|c|}{$\begin{array}{lr}\text { Fish length }(\mathrm{mm}) \\
\bar{x} \quad \text { (range) }\end{array}$} & $\mathrm{N}$ & $E$ & $\begin{array}{c}\text { Prop. } \\
\text { zoopl. } \\
(\%)\end{array}$ & $\begin{array}{c}\text { No. of } \\
\text { identified } \\
\text { prey }\end{array}$ & \multicolumn{3}{|c|}{$\begin{array}{l}\text { Copepoda } \\
\text { (ad\&cop.) }\end{array}$} & \multicolumn{2}{|c|}{ Cladocera } & $\begin{array}{l}\text { Other } \\
\text { zoopl. }\end{array}$ \\
\hline \multicolumn{14}{|l|}{ Sprat } \\
\hline \multirow[t]{2}{*}{ Jul 4} & 1 & 88 & $(85-90)$ & 4 & 2 & 100 & 18 & 0 & 0 & 0 & 0 & 100 & 0 \\
\hline & 5 & 88 & $(82-110)$ & 13 & 3 & 100 & 474 & 7 & 0 & 1 & 18 & 51 & $25^{b}$ \\
\hline \multirow[t]{3}{*}{ Aug 1} & 1 & 95 & $(84-142)$ & 11 & 1 & 99 & 329 & 16 & 0 & 1 & 49 & 33 & 2 \\
\hline & 3 & 94 & $(85-97)$ & 10 & 0 & 100 & 1015 & 20 & 0 & 2 & 77 & 2 & 0 \\
\hline & 5 & 90 & $(87-93)$ & 10 & 1 & 100 & 633 & 30 & 0 & 1 & 69 & 1 & 0 \\
\hline \multirow[t]{3}{*}{ Aug 28} & 1 & 115 & $(85-144)$ & 15 & 5 & 100 & 729 & 1 & 0 & 0 & 93 & 6 & 0 \\
\hline & 3 & 122 & $(120-124)$ & 3 & 0 & 100 & 132 & 23 & 1 & 1 & 74 & 0 & 2 \\
\hline & 5 & 108 & $(71-147)$ & 5 & 0 & 100 & 500 & 0 & 0 & 0 & 100 & 0 & 0 \\
\hline Sep 24 & 1 & 108 & $(71-147)$ & 5 & 2 & 100 & 57 & 25 & 0 & 2 & 57 & 17 & 0 \\
\hline \multirow[t]{2}{*}{ Oct 23} & 1 & 120 & & 1 & 0 & 100 & 100 & 36 & 25 & 15 & 0 & 24 & 0 \\
\hline & 3 & 109 & $(60-142)$ & 4 & 1 & 100 & 45 & 64 & 2 & 0 & 0 & 29 & 6 \\
\hline \multicolumn{14}{|c|}{ YOY herring } \\
\hline \multirow[t]{2}{*}{ Aug 28} & 1 & 80 & $(72-87)$ & 10 & 0 & 100 & 705 & 12 & 0 & 0 & 84 & 4 & 0 \\
\hline & 3 & 72 & $(62-83)$ & 10 & 0 & 100 & 897 & 5 & 0 & 0 & 95 & 0 & 0 \\
\hline \multirow[t]{3}{*}{ Sep 24} & 1 & 85 & $(81-90)$ & 10 & 0 & 100 & 506 & 8 & 1 & 1 & 64 & 25 & 2 \\
\hline & 3 & 65 & $(55-75)$ & 11 & 0 & 95 & 332 & 25 & 0 & 2 & 23 & 40 & $14^{\mathrm{C}}$ \\
\hline & 5 & 83 & $(73-90)$ & 10 & 0 & 100 & 530 & 90 & 1 & 0 & 3 & 2 & 3 \\
\hline Oct 23 & 1 & 85 & $(84-86)$ & 4 & 0 & 100 & 92 & 37 & 24 & 6 & 8 & 25 & 0 \\
\hline & 3 & 66 & $(62-75)$ & 11 & 0 & 100 & 431 & 7 & 7 & 14 & 5 & 21 & $46^{\mathrm{d}}$ \\
\hline & 5 & 80 & $(64-93)$ & 10 & 0 & 100 & 114 & 92 & 2 & 1 & 0 & 6 & 0 \\
\hline I+ herri & & & & & & & & & & & & & \\
\hline Jul 4 & 5 & 91 & $(80-108)$ & 3 & 0 & 100 & 228 & 22 & 1 & 0 & 10 & 17 & $50^{\mathrm{b}}$ \\
\hline Aug 1 & 1 & 107 & $(98-122)$ & 11 & 3 & 100 & 252 & 36 & 0 & 2 & 47 & 12 & 2 \\
\hline & 3 & 117 & $(93-133)$ & 16 & 0 & 100 & 616 & 25 & 0 & 4 & 69 & 0 & 1 \\
\hline & 5 & 113 & $(106-130)$ & 5 & 0 & 100 & 500 & 7 & 0 & 0 & 93 & 0 & 0 \\
\hline Aug 28 & 1 & 125 & $(118-134)$ & 9 & 2 & 100 & 300 & 41 & 0 & 0 & 58 & 1 & 0 \\
\hline & 3 & 122 & $(115-134)$ & 10 & 1 & 100 & 811 & 47 & 0 & 0 & 53 & 0 & 0 \\
\hline & 5 & 124 & $(115-133)$ & 9 & 0 & 100 & 900 & 2 & 0 & 0 & 98 & 0 & 0 \\
\hline Sep 24 & 1 & 122 & $(107-136)$ & 10 & 2 & 97 & 162 & 41 & 0 & 0 & 57 & 2 & 1 \\
\hline & 3 & 113 & & 1 & 0 & 50 & 0 & & & Only & plankt & on egg & \\
\hline Oct 23 & 5 & 123 & $(118-131)$ & 10 & 0 & 100 & 418 & 94 & 4 & 0 & 1 & 0 & 0 \\
\hline Older $\mathbf{h}$ & ring & & & & & & & & & & & & \\
\hline Jul 4 & 1 & 191 & $(137-249)$ & 8 & 6 & 50 & 0 & & & Only & plankt & on egg & \\
\hline & 5 & 196 & $(176-233)$ & 8 & 4 & 98 & 377 & 30 & 0 & 0 & 2 & 58 & $10^{b}$ \\
\hline Aug 1 & 1 & 199 & $(162-261)$ & 9 & 3 & 100 & 5 & 60 & 0 & 0 & 40 & 0 & 0 \\
\hline & 3 & 197 & $(178-217)$ & 10 & 2 & 100 & 484 & 33 & 0 & 0 & 67 & 0 & 0 \\
\hline & 5 & 198 & $(150-220)$ & 7 & 1 & 100 & 308 & 4 & 0 & 0 & 93 & 3 & 0 \\
\hline Aug 28 & 1 & 185 & $(168-207)$ & 9 & 0 & 90 & 87 & 27 & 0 & 2 & 70 & 0 & 0 \\
\hline & 3 & 195 & $(183-207)$ & 5 & 0 & 80 & 173 & 87 & 1 & 0 & 12 & 0 & 0 \\
\hline & 5 & 153 & $(142-166)$ & 7 & 0 & 86 & 408 & 2 & 0 & 0 & 98 & 0 & 0 \\
\hline Sep 24 & 1 & 174 & $(142-219)$ & 9 & 4 & 79 & 15 & 39 & 6 & 31 & 0 & 0 & 25 \\
\hline & 3 & 162 & $(148-178)$ & 8 & 0 & 88 & 103 & 56 & 0 & 6 & 23 & 14 & 0 \\
\hline & 5 & 163 & $(148-186)$ & 10 & 0 & 100 & 909 & 99 & 1 & 0 & 0 & 0 & 0 \\
\hline Oct 23 & 1 & 188 & $(165-208)$ & 7 & 1 & 5 & 3 & 67 & 0 & 0 & 33 & 0 & 0 \\
\hline & 3 & 186 & $(150-250)$ & 10 & 8 & 50 & 50 & 92 & 2 & 2 & 4 & 0 & 0 \\
\hline & 5 & 169 & $(150-202)$ & 10 & 2 & 88 & 117 & 95 & 0 & 0 & 5 & 0 & 0 \\
\hline $\begin{array}{l}\text { a Prima } \\
\text { b Prima } \\
\text { c Prima } \\
\text { d Prima }\end{array}$ & $\begin{array}{l}\text { y } A C a \\
\text { y } B a l \\
\text { y } K e r \\
\text { y cop }\end{array}$ & $\begin{array}{l}\text { Is naup } \\
\text { lla } \\
\text { od naur }\end{array}$ & & & & & & & & & & & \\
\hline
\end{tabular}


ity but there were consistent patterns of prey preference throughout the study period. The mysids selected cladocerans (Bosmina longispina and Pleopsis polyphemoides) over copepods, especially Acartia sp. (Fig. 3). Comparable values for rotifers and tintinnids were not calculated because they represented a small portion of the diet.

Fish. Sprat and young herring fed almost exclusively on zooplankton throughout the study period while older herring also fed on other food items (primarily mysids and fish) in early July and in October (Table 6). The zooplankton species in the diet of the clupeids reflected prey availability (Table 6, Fig. 2). Copepod nauplii were present in fish caught in October when the proportion of nauplii in the water was high. In early and late August, Bosmina longispina dominated the YOY herring and sprat diets and both $B$. longispina and copepods were found in older herring. Pleopsis polyphemoides was consumed in early summer and in the autumn when this was the most common cladoceran. Copepods were the dominant prey item in all clupeids in October (Table 6). Rotifers were rare and intinnids absent. Ciupeids, especially sprat and young herring, selected cladocerans over copepods and Eurytemora/Temora copepods over other copepod species (Fig. 3). These patterns of selectivity were consistent over the seasons and among sampling areas.

\section{Consumption rates}

Calculated specific consumption of Mysis mixta juveniles declined from $14 \% \mathrm{~d}^{-1}$ at the beginning of the summer to $4 \% \mathrm{~d}^{-1}$ at the end of October. Consumption per mysid was similar from August 1 to October 23 as lower specific consumption rates in the autumn were compensated by increased mysid size. Daily consumption was up to $50 \%$ higher in the Bay than in the Asko area as the mysids grew faster in the Bay. Specific consumption rates of herring during the summer was 10 to $20 \%$ of body weight $\mathrm{d}^{-1}$ for YOY fish larger than $5 \mathrm{~cm}, 7$ to $13 \% \mathrm{~d}^{-1}$ for I+ fish, and ca 4 to $5 \% \mathrm{~d}^{-1}$ for older age groups. These consumption rates declined to 2 to $4 \% \mathrm{~d}^{-1}$ by the end of October for all age classes. Similar specific consumption rates have been reported elsewhere from experiments and field estimates of daily food rations (mysids: Bowers \& Vanderploeg 1982; YOY herring: Franek 1988).

Abundances of different planktivores were combined with their calculated daily consumption rates to yield an estimate of total consumption of zooplankton. Planktivory by fish increased from early July to a maximum in August (Fig. 4). Consumption rates declined in the autumn although fish abundance increased. This is the result of smaller average fish sizes, slow growth and
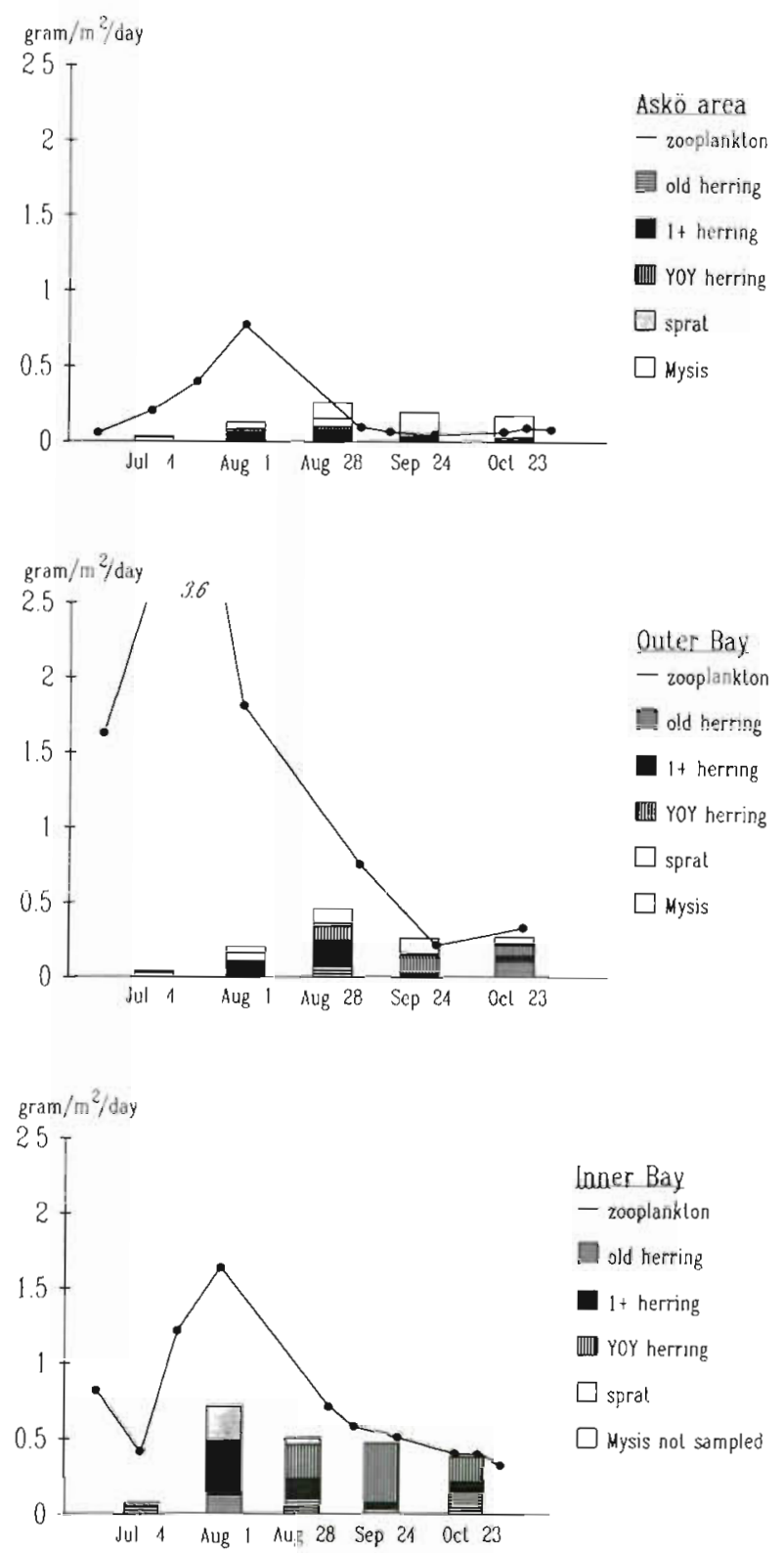

Fig. 4. Estimated zooplanktivory rates and zooplankton production rates (in $g$ wet $w \mathrm{~m}^{-2} \mathrm{~d}^{-1}$ ) in the Inner Bay, the Outer Bay and the Askö area. Zooplanktivory rates (bars) show the contributions from different predators on 5 occasions from July 4 to October 23, 1985. Mysids and fish larvae are not included in the Inner Bay. Line: zooplankton production calculated using samples collected at shorter time intervals; $(\bullet)$ sampling dates. Production estimates for the Inner Bay are based on averages for samples collected at Stns $4 \& 5$

low temperatures. Sprat and yearling herring dominated during late summer (August 1 and 28). The contribution from YOY herring was high from the end of August through October. Older herring were less important planktivores and clupeid larvae contributed at the most $4 \%$ of the total planktivory. Mysis mixta 
was less important in the Outer Bay than in the Askö area, were it was the dominant planktivore in the autumn (Fig. 4).

\section{Comparison of planktivory and zooplankton production}

Zooplankton daily production increased through the summer, peaked in August and decreased thereafter (Fig. 4). This pattern was similar in all 3 areas. Production interpolated over the period 15 June to 15 November increased by a factor of 3 to 5 between the Askö area and the Bay (Table 7). Crustacean zooplankton production accounted for 85 to $97 \%$ of total zooplankton production (larger than $90 \mu \mathrm{m}$; Table 7).

Consumption of zooplankton by planktivores was lower than zooplankton production on July 4 and August 1 and higher than or similar to zooplankton production on August 28, September 24 and October 23 (Fig. 4). The ratio between zooplanktivory and production of crustacean zooplankton interpolated from 15 June to 15 November was similar in the Inner Bay and in the Askö area (0.7) and lower in the Outer Bay (0.3).

The patterns for individual prey groups are similar to the observations for zooplankton in general with higher zooplanktivory relative to production in late August through October (Fig. 5). Planktivory rates on Bosmina longispina maritima peak earlier (early and late August) than planktivory on Eurytemora/Temora (late August through October) which is consistent with the earlier decrease of cladoceran (Fig. 2). The patterns are less clear for the 2 less abundant prey groups (Pleopsis polyphemoides and other copepods, primarily Acartia spp.) shown in Fig. 5.

\section{DISCUSSION}

\section{Identification of major planktivores}

Our calculations show that the dominant zooplanktivores in this area in 1985 were sprat, herring and Mysis mixta. The relative importance of these predators changed both seasonally and spatially. $M$. mixta was the major planktivore in the Askö area but not in the Outer Bay. Sprat and yearling herring were important in the summer and YOY herring in the autumn. The contribution from older herring was fairly similar over the sampling period and among areas. Unfortunately, we do not have information on mysids and fish larvae from the Inner Bay in 1985 but results from other years suggest lower abundances than in the Outer Bay (Rudstam et al. 1986, Rudstam \& Hansson 1990).

Other planktivores contributed only marginally to
Table 7. Estimations of planktivory and zooplankton production for selected zooplankton groups for the period June 15 to November 15 1985. The estimates are based on interpolations between sampling dates. Planktivory by mysids is not included for the Inner Bay. The production value in parentheses for copepods excludes egg production. Zooplankton production not accounted for by crustaceans are primarily from rotifers (Synchaeta and Keratella)

\begin{tabular}{lrrr} 
Zooplankton group & $\begin{array}{r}\text { Production } \\
\text { (g wet wt } \mathrm{m}^{-2} \text { ) }\end{array}$ \\
\hline Askö area & & & \\
All zooplankton & 35 & 23 \\
Bosmina & 1 & 6 \\
Other cladocerans & 1 & 2 \\
Eurytemora/Temora & 15 & $(8)$ & 11 \\
Other copepods & 18 & $(9)$ & 4 \\
Outer Bay & & & \\
All zooplankton & 172 & & 36 \\
Bosmina & 22 & & 11 \\
Other cladocerans & 58 & & 2 \\
Eurytemora/Temora & 46 & $(29)$ & 21 \\
Other copepods & 11 & $(4)$ & 2 \\
Inner Bay & & & \\
All zooplankton & 113 & & 64 \\
Bosmina & 26 & & 31 \\
Other cladocerans & 6 & & 1 \\
Eurytemora/Temora & 59 & $(41)$ & 31 \\
Other copepods & 6 & $(4)$ & 1 \\
& & &
\end{tabular}

the overall zooplankton consumption. Clupeid larvae accounted at the most for $4 \%$ of the total zooplanktivory. Sand gobies did contain zooplankton, but because of their small size would contribute less than $3 \%$ of total planktivory (given abundances derived from Bongo net catches, a specific consumption rate of $20 \%$ and a diet of $100 \%$ zooplankton). Neomysis integer do feed on zooplankton (Hansson et al. 1990a) but were mostly smaller than $7 \mathrm{~mm}$ and contributed less than $3 \%$ of the total mysid biomass. There were no other potentially important invertebrate predators on crustacean zooplankton present. The coelenterate Aurelia aurita, considered an important planktivore in the southern Baltic (Möller 1979), was rare in 1985.

Seasonal changes in proportions of copepods and cladocerans consumed by both mysids and young clupeids reflected the seasonal changes in zooplankton species composition, but there were consistent patterns of prey selection by both groups. Cladocerans (Bosmina longispina maritima and Pleopsis polyphemoides) were selected over copepods and Eurytemora/Temora were selected over other copepod species. This is similar to earlier observations in this area (Hansson et al. 1990a), to results for mysids elsewhere (Lasenby \& Fürst 1981, Murtaugh 1981), and to reports for Baltic herring and sprat (Sandström 1980, Shvetsov et al. 1983). Eurytemora affinis hirundoides is 


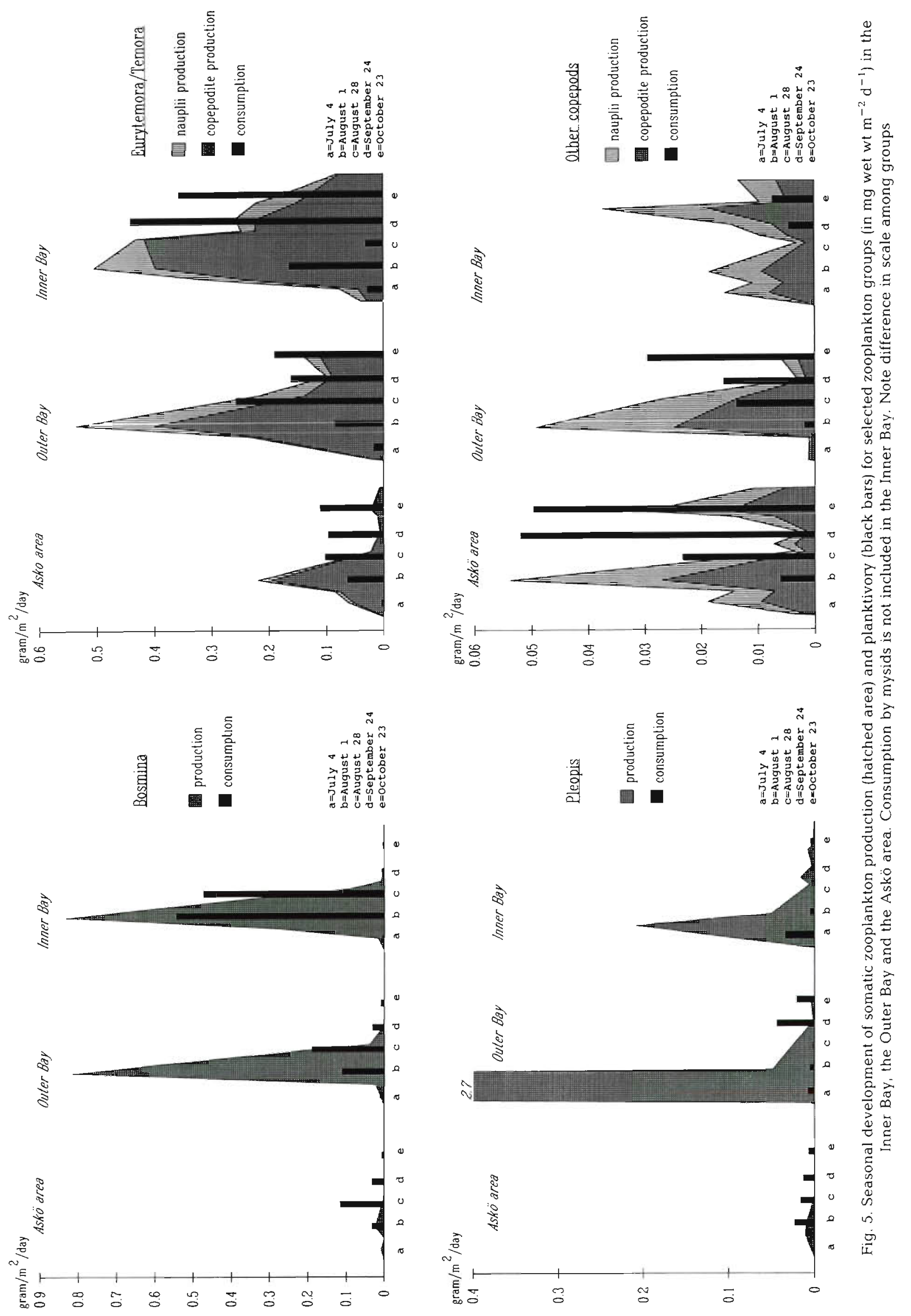


a more active copepod when observed in the laboratory and the high selectivity for this species compared to other copepods by all predators could reflect differences in encounter or detection rates. Fish often choose moving over non-moving prey (O'Brien et al. 1984).

\section{Reliability of production and planktivory estimates}

Except for the Inner Bay where we sampled 2 stations, we have no information on the spatial variation in zooplankton abundance for 1985. Later studies in the Askö area indicate a coefficient of variation of 40 to $50 \%$ for dominating taxa (Johansson et al. unpubl.). Our data from the 2 stations in the Inner Bay gave similar results.

Our production estimates are based on temperaturedependent growth equations and daily production/biomass ratios and we did not consider differences in food availability. Cohort analysis based on field samples was not possible due to continuous reproduction of these species during the summer, a common problem with marine zooplankton (Kimmerer 1987). The equations used for copepods are based on experiments on populations that were not food limited and we consider these estimates to represent maximum potential consumption. Somatic production of coastal herbivorous copepods is often not food limited (Huntley \& Boyd 1984) although egg production often is (Kiørboe et al. 1985). The assumptions made for Eurytemora affinis hirundoides are supported by experiments in large plastic bags conducted in July 1989. Generation time was estimated to $14 \mathrm{~d}$ at $17.5^{\circ} \mathrm{C}$ both at chlorophyll concentrations typical of the Askö area and at those of the Inner Bay. (Johansson pers. obs.). This should be compared to the $15 \mathrm{~d}$ calculated from the equation used in this paper (Vuorinen 1982). However, egg production was only observed in the bags with higher chlorophyll concentrations. Thus, we believe that our copepod production estimates are reasonable in the Bay but may be high in the Askö area. Cladocerans generally respond to increased food availability by increased production (DeMott 1989) and we may therefore have underestimated the differences in cladoceran production between the Bay and the Askö area.

Mysid abundances are based on catches in Bongo nets, which are considered an effective sampling gear for the similarly sized euphausiids (Pearcy et al. 1980). Duplicate Bongo net samples gave results within 3 to $32 \%$ of the mean for Mysis mixta (Table 3; see also Rudstam et al. 1986). Abundances are similar to those obtained in 1983, 1984 and 1986 in this area (Rudstam \& Hansson 1990) and elsewhere in the Baltic (Salemaa et al. 1986). Our estimates are lower bounds for total mysid abundances because part of the population occurs on the bottom at night, especially in the Askö area (Rudstam et al. 1989a). We will have underestimated planktivory by mysid shrimps if the mysids caught on the bottom also feed in the water column during part of the night.

Fish abundances are based on the species and size distribution in vertical gill net catches and the total abundances from acoustics. On 5 occasions in 1985, we recorded 3 or more repeated acoustic transects over a $24 \mathrm{~h}$ period in the Askö area and in the Bay. Coefficients of variation for the abundance of fish over $5 \mathrm{~cm}$ length ranged from 13 to $52 \%$ (average $32 \%$ ). The gill nets used had very low selectivity for fish below 5 to $6 \mathrm{~cm}$ length and we may have underestimated the number of YOY clupeids in August. However, the small number of YOY herring caught in the Bongo net in August compared to September and October (when these fish are larger and better able to avoid the Bongo net) indicate that YOY herring were uncommon in August in our area. Urho \& Hildén (1990) reported that small YOY herring stay close to shore in an archipelago area on the Finnish side of the Baltic Sea.

Results from stomach analysis is potentially biased by differential gut passage times and digestibility, especially when prey items are very different in size (Bowen 1983). However, we are primarily using stomach contents to estimates proportions of similarly sized zooplankton species. Only older herring fed on larger prey items. Clupeids feed continuously throughout the day but not at night (Nellbring 1975, Shvetsov et al. 1983) and stomach content of fish caught in the first part of the night should reflect day time food intake. For mysids, Rybock (1978) found no significant differences between gut passage times for different zooplankton mandibles in mysid stomachs. Mysids feed during the night and the zooplankton were collected during the day, but zooplankton species composition and abundance from integrated water column samples for day and night are similar (Rudstam 1988, Hansson et al. 1990a).

Total planktivory is calculated as $\sum A_{j} \cdot C_{j}$, where $A_{j}$ is the abundance of predator $j$, and $C_{j}$ is its daily zooplankton consumption. The coefficients of variation associated with the abundance measures are ca $20 \%$ for Mysis mixta and $30 \%$ for fish (see above). The variance associated with the daily consumption rates are harder to estimate since they are based on nonlinear models with many parameters. A coefficient of variation for the daily consumption estimated of $30 \%$ may be reasonable. First-order error analysis (Carpenter 1984) yields estimate for the coefficient of variation for total planktivory rates ranging from 20 to $35 \%$ for the different sampling occasions and areas. Thus, the observed order of magnitude changes in planktivory rates from low values in early July to high values in August are real. 


\section{Seasonal patterns of planktivory and zooplankton production}

Zooplanktivory changed dramatically during the study period. Consumption of zooplankton was low in early July because clupeids were rare and because Mysis mixta were small and did not utilize the open water, possibly due to the high light levels around midsummer at these latitudes (Rudstam et al. 1989a). Planktivory peaked in late summer as a result of immigration of sprat and yearling herring, increased abundance of YOY herring (probably recruited from shallow water areas) and increased planktivory from M. mixta as the juveniles released in the spring grew in size and darker nights made the water column accessible for mysids. A peak in planktivory by YOY fish in late summer and autumn is also typical in temperate lakes (Mills et al. 1987, Hewett \& Stewart 1989). Zooplanktivory declines in the autumn as a result of slower growth at lower temperatures, and a shift in diet of older herring to mysids and fish. The increase in planktivory follows the seasonal increase in zooplankton biomass with comparatively short time lags (about 1 mo in this area), which may be necessary for planktivores to control seasonal zooplankton cycles (Gliwicz \& Pijanowska 1989, Luecke et al. 1990).

Because this seasonal dynamic in zooplanktivory is caused partly by ontogenetic changes in behavior and seasonal changes in light levels, it may be repeated each year. Year to year variation in absolute levels of planktivory may however be substantial due to notoriously variable year class strength of planktivores (Sissenwine 1984). Fish abundances in late summer autumn varied by a factor of 4 in the Askö area and a factor of 5 in the Inner Bay for the years 1985 to 1988 (0.16 to $0.7 \mathrm{fish} \mathrm{m}^{-2}$ in the Askö area and 1 to 5 fish $\mathrm{m}^{-2}$ in the Inner Bay; Hansson \& Rudstam 1990).

We suggest that the increase in planktivory caused the late summer - autumn decline in zooplankton abundances. Consumption of zooplankton was lower than zooplankton production in early summer when zooplankton biomass increased, and higher or similar to production in late summer and autumn when zooplankton biomass decreased in all 3 areas (Figs. 2 \& 4). Alternatively, the decline could be the result of resting egg production or low food concentrations. However, previous studies in this area show that parthenogenetic females of Bosmina longispina maritima dominate at least through the middle of September (Kankaala 1983), indicating that resting egg production did not cause the August decline of this species. Unfortunately, we do not know when the copepods produce resting eggs. The autumn decrease in zooplankton abundances is probably not caused by food shortage. Chlorophyll levels in September and October were similar to (Askö area) or higher than (Inner Bay) levels in July and August 1985 (Larsson et al. 1991).

\section{Differences among the study areas}

The planktivores were estimated to consume about $70 \%$ of crustacean zooplankton production both in the Inner Bay and in the Askö area even though zooplankton production was 3 times higher in the Bay. This ratio was $30 \%$ for the Outer Bay, but this is probably too low since zooplankton production in that area depended strongly on samples from one date (July 16) with unusually high abundances of the cladoceran Pleopsis polyphemoides (Fig. 2). The similarity between the independently derived consumption and production estimates indicate that most of the annual crustacean zooplankton production is consumed by the predators. For specific prey groups, the comparisons between estimates of production and consumption in the 3 areas are more variable, reflecting the increased uncertainties associated with including information from diet analysis in the estimates. The proportions of somatic production of Eurytemora/Temora consumed by planktivores were close to 1 in all areas even though the estimated production was 4 times higher in the Inner Bay than in the Askö area. Consumption of Bosmina was higher than production estimates in the Inner Bay and in the Askö area and lower in the Outer Bay (Fig. 5, Table 7 ; see also Hansson et al. 1990a).

The zooplankton seasonal dynamics and species composition show indications of larger effects of planktivory in the Askö area than in the Bay. The most selected species (cladoceran and Eurytemora copepods) were a smaller proportion of total zooplankton biomass and declined earlier in the season in the Askö area than in the Inner Bay. The high summer abundances of cladocerans in the Bay may actually delay an autumn decline in copepod biomass because YOY and juvenile clupeids selected cladocerans over copepods. Although the ratio between planktivory and zooplankton production was similar in the Inner Bay and the Askö area, these production estimates represent potential, not food limited, zooplankton production. Food limited zooplankton production is more likely in the Askö area than in the Bay. Predatory regulation of zooplankton dynamics will interact with food limited growth (Gliwicz \& Pijanowska 1989) and this interaction probably produces the observed differences among our study areas.

\section{Final remarks}

The zooplankton assemblage present in this part of the Baltic Sea shows signs of being strongly affected by 
predation. Both the cladoceran and copepod species present are comparatively small, the preferred copepods have marked diel vertical migrations (Hansson et al. 1990a) and most of the annual crustacean production is consumed (this study). Also, daphnids, which are sensitive to predation, were completely absent although they occur in comparable salinities in an eastern Baltic archipelago (Vuorinen \& Ranta 1987). The abundances and biomass of planktivorous fish in the area (reaching 2 fish $\mathrm{m}^{-2}$ and $10 \mathrm{~g} \mathrm{~m}^{-2}$ in the Inner Bay in the autumn) are larger than the abundance of YOY perch Perca flavescens causing the disappearance of Daphnia pulex in Oneida Lake, New York, USA (1.4 fish $\mathrm{m}^{-2}$ or 2 to $4 \mathrm{~g} \mathrm{~m}^{-2}$; Mills et al. 1987) and the estimated biomass of alewife Alosa pseudoharengus in Lake Michigan in 1976 associated with low abundances of larger daphnids $\left(1.3 \mathrm{~g} \mathrm{~m}^{-2}\right.$; Scavia et al. 1988). We have shown here that planktivory varies substantially over the season and that the increase in planktivory in the late summer and autumn is correlated with the seasonal decline of the zooplankton populations. Thus, the importance of planktivory for regulating zooplankton populations in the Baltic Sea changes with season, as suggested by Roff et al. (1988) for the North Sea (see also Viitasalo et al. 1990).

Acknowledgements. We are grateful to the director of the Center for Limnology, John Magnuson, for hospitality and support during L.G.R.'s visits. Jim Kitchell and Don Stewart explained the bioenergetics models and C. S. Clay and Tim Stanton provided laboratory space and help with acoustic signal processing. Ragnar Elmgren, Chris Luecke, Bengt-Owe Jansson and Ann-Marie Jansson gave helpful suggestion on the manuscript. Karin Kers, Orfelina Araya, Harriet Hill, Inger Hafdell, Gunilla Pettersson, Nicki Bagger, Berndt Abrahamsson, Gösta Rudstam, Katarina Skärlund and Alberto Cortés helped in the field or with data analysis. Financial support was provided by the Swedish Environmental Protection Board and the Trygger, Salén, Engkvist, Längman, Liljevalch, SwedishAmerican Foundations and by the Swedish Institute. The paper was completed while L.G.R. was a postdoctoral fellow of the Swedish Council for Forestry and Agricultural Research at the University of Wisconsin, Madison.

\section{LITERATURE CITED}

Aneer, G. (1975). A two year study of the Baltic herring in the Askö-Landsort area, 1970-72. Contr. Askö Lab., Univ. Stockholm 8: 1-36

Aneer, G. (1980). Estimated of feeding pressure on pelagic and benthic organisms by Baltic herring (Clupea harengus v. membras L.). Ophelia, Suppl. 1: 265-275

Aneer, G. (1985). Some speculations about the Baltic herring (Clupea harengus membras) in connection with the eutrophication of the Baltic Sea. Can. J. Fish. Aquat. Sci. 42 (Suppl. 1): 83-90

Bowen, S. H. (1983). Quantitative description of the diet. In: Nielsen, L. A., Johnson, D. L. (eds.) Fisheries techniques. American Fisheries Society, Bethesda, Maryland, p. $325-336$
Bowers, J. A., Vanderploeg, H. A. (1982). In situ predatory behavior of Mysis relicta in Lake Michigan. Hydrobiologia 93: $121-131$

Brooks, J. L., Dodson, S. I. (1965). Predation, body size, and composition of zooplankton. Science 150: 28-35

Carpenter, S. R. (1984). First-order error analysis of aquatic plant production estimates. In: Dennis, W M., Isom, B. G. (eds.) Ecological assessment of macrophyton: collection, use and meaning of data. American Society for Testing and Materials, p. 36-45

Carpenter, S. R., Kitchell, J. F., Hodgson, J. R. (1985). Cascading trophic interactions and lake productivity. Bioscience 35: 634-639

Checkley, D. M. Jr (1984). Relation of growth to ingestion for larvae of Atlantic herring Clupea harengus and other fish. Mar. Ecol. Prog. Ser. 18: 215-224

Chesson, J. (1983). The estimation and analysis of preference and its relationship to foraging models. Ecology 64: $1297-1304$

Davis, C. S. (1984). Predatory control of copepod seasonal cycles on Georges Bank. Mar Biol. 82: 31-40

Deason, E. E., Smayda, T. J. (1982). Ctenophore-zooplanktonphytoplankton interactions in Narragansett Bay, Rhode Island, USA, during 1972-1977. J. Plankton Res. 4: 203-217

DeMott, W. R. (1989). The role of competition in zooplankton succession. In: Sommer, U. (ed.) Plankton ecology. Springer Verlag, Berlin, p. 195-252

Dodson, S. I. (1974). Zooplankton competition and predation: an experimental test of the size efficiency hypothesis. Ecology 55: 506-613

Elmgren, R., Larsson, U. (1987). Eutrofiering av havs och kustområden. Nordforsk Miljövårdsserien 1987, 1: 297-319

Franek, D. (1988). O+ (Osmerus eperlanus L.) and herring (Clupea harengus L.) in the food chain of the Bather Bodden. ICES Symposium BAL/No. 12: 1-9

Fulton, R. S. III (1985). Predator-prey relationships in an esturarine littoral copepod community. Ecology 66: 21-29

Gliwicz, Z. M., Pijanowska, J. (1989). The role of predation in zooplankton sucession. In: Sommer, U. (ed.) Plankton ecology. Springer Verlag, Berlin, p. 253-296

Hansson, S. (1988). A simple vertical gill net system for variable current conditions. Hydrobiologia 160: 107-110

Hansson, S., Rudstam, L. G. (1990). Eutrophication and Baltic fish communities. Ambio 19: 123-125

Hansson, S., Rudstam, L. G., Larsson, U. (1987). Pelagial fisk i Norra Östersjöns kustområden - resultat av ekolodsundersökningar i skärgårdsområdena i Stockholms, Södermanlands och Östergötlands län. Askö Lab. Tech. Rep. 1

Hansson, S., Larsson, U., Johansson, S. (1990a). Selective predation by herring and mysids on Baltic coastal zooplankton communities. J. Plankton Res. 12: 1099-1116

Hansson, S., Rudstam, L. G., S. Johansson, S. (1990b). Are marine plantonic invertebrates food limited? The case of Mysis mixta (Crustacea, Mysidacea) in the Baltic Sea. Oecologia 80: 4330-4332

Hernroth, L. (1985). Recommendations on methods for marine biological studies in the Baltic Sea. Mesozooplankton assessment. Baltic Marine Biologist Publ. No. 10: 1-32

Hewett, S. W., Johnson, B. L. (1987). A generalized bioenergetics model of fish growth for microcomputers. University of Wisconsin Sea Grant Institute, Madison, Wisconsin

Hewett, S. W., Stewart, D. J. (1989). Zooplanktivory by alewives in Lake Michigan: Ontogenetic, seasonal and historical patterns. Trans. Am. Fish. Soc. 118: 581-596

Horsted, S. J., Nielsen, T G., Reimann, B., Pock-Steen, J., 
Bjornsen, P. K. (1988). Regulation of zooplankton by suspension-feeding bivalves and fish in estuarine enclosures. Mar. Ecol. Prog. Ser 48: 217-224

Hrbacek, J., Dvorakova, M., Korinak, V., Prochazkova, L. (1961). Demonstration of the effect of the fish stock on the species composition of zooplankton and the intensity of metabolism of the plankton association. Verh. int. Verein. Limnol. 14: 192-195

Huntley, M., Boyd, C. (1984). Food-limited growth of marine zooplankton. Am. Nat. 124: 455-478

Johansson, S. (1983). Annual dynamics and production of rotifers in an eutrophication gradient in the Baltic Sea. Hydrobiologia 105: 335-340

Kankaala, P. (1983). Resting eggs, seasonal dynamics, and production of Bosmina longispina maritima (P. E. Müller) (Cladocera) in the northern Baltic proper. J. Plankton Res. 5: 53-69

Kankaala, P. (1984). A quantitative comparison of two zooplankton sampling methods, a plankton trap and a towed net, in the Baltic. Int. Rev. ges. Hydrobiologia 69: 277-287

Kankaala, P., Alasaarela, E., Sundberg, E. (1984). Phytoplankton and zooplankton production in the northeastern and central Bothnian Bay - a review of studies carried out in 1968-1978. Ophelia Suppl. 3: 69-88

Kimmerer, W. J. (1987). The theory of secondary production calculations for continuously reproducing populations. Limnol. Oceanogr. 32: 1-13

Kinmerer, W. J., McKinnon, A. D. (1989). Zoopiankton in a marine bay. III. Evidence for influence of vertebrate predation on distributions of two common copepods. Mar Ecol. Prog. Ser. 53: 21-53

Kiørboe, T., Mohlenberg, F., Hamburger, K. (1985). Bioenergetics of the planktonic copepod Acartia tonsa: implications for the determination of copepod production. Mar. Biol. 99: 341-352

Kiørboe, T., Munk, P. (1986). Feeding and growth of larval herring, Clupea harengus, in relation to density of copepod nauplii. Environ. Biol. Fish. 17: 133-139

Kuipers, B. R., Gaedke, U., Enserink, L. Witte, H. (1990). Effect of ctenophore predation on mesozooplankton during a spring outburst of Pleurobrachi pileus. Neth. J. Sea Res. 26: $111-124$

Landry, M. R. (1978). Population dynamics and production of a planktonic marine copepod Acartia clausii, in a small temperate lagoon on San Juan Island, Washington. Int. Rev. ges. Hydrobiol. 63: 77-119

Larsson, U. (1986). Intensiv övervakning av kustvatten i AsköLandsortsområdet. Swedish Environmental Protection Board Rapport 3250: 1-53

Larsson, U., A. Sjösten, Johansson, S. (1991). Himmerfjärdsundersökningen. Askö Lab. Tech. Rep. 7

Lasenby, D. C., Fürst, M. (1981). Feeding of Mysis relicta Lovén on macrozooplankton. Rep. Inst. Freshw. Res., Drottningholm 59: 75-80

Laurence, G. C. (1976). Caloric content of some North Atlantic calanoid copepods. Fish. Bull. U.S. 78: 218-220

Lonsdale, D. J. (1981). Regulatory role of physical factors and predation to two Chesapeake Bay copepod species. Mar Ecol. Prog. Ser. 5: 341-351

Luecke, C., Vanni, M. J., Magnuson, J. J., Kitchell, J. F., Jacobson, P. T (1990). Seasonal regulation of Daphnia populations by planktivorous fish: implications for the spring clearwater phase. Limnol. Oceanogr. 35: 1718-1733

McLaren, I. A. (1978). Generation length of some temperate marine copepods: estimation, prediction and implications. J. Fish. Res. Bd Can. 35: 1330-1342

Mills, E. L., Forney, J. L., Wagner, K. J. (1987). Fish predation and its cascading effect on the Oneida Lake food chain. In: Kerfoot, W. C., Sih, A. (ed.) Predation. Direct and indirect impacts on aquatic communities. University Press, Hanover, New Hampshire, p. 118-131

Möller, H. (1979). Significance of coelenterates in relation to other plankton organisms. Meeresforsch. 27: 1-18

Murtaugh, P. A. (1981). Selective predation by Neomysis mercedis in Lake Washington. Limnol. Oceanogr. 26: 445-453

Nellbring, S. (1975). En jämförande undersökning av näringsval och kondition hos strömming och skarpsill. B. Sc. thesis, Dept of Zoology, Univ. of Stockholm

Nixon, S. W. (1982). Nutrient dynamics, primary production and fisheries yield of lagoons. Oceanol. Acta 1982: $357-371$

O'Brien, W J., Evans, B., Luecke, C. (1984). Apparent size choice of zooplankton by planktivorous sunfish: exceptions to the rule. Environ. Biol. Fish. 13: 225-233

Ohman, M. D. (1986). Predator-limited population growth of the copepod Pseudocalanus sp. J. Plankton Res. 8: 673-713

Pearcy, W. G., Greenlaw, C. F., Pommeranz, T. (1980). Assessment of euphausiids with five nets and a $120 \mathrm{kHz}$ echosounder in fjords of northern Norway. Biol. Oceanogr. 2: $151-177$

Pourriot, R., Deluzarchez, M. (1971). Recherches sur la biologie des rotiferes. II. Influence de la température sur la durée du dévelopment embryonnaire et post-embryonnaire. Ann. Limnol. 7: 25-52

Powell, L. A., Stanton, T K. (1983). A programmable microcomputer-based sonar echo processor for real-time processing. IEEE J. Ocean. Eng. OE-8: 280-286

Roff, J. C., Middlebrook, K., Evans, F. (1988). Long-term variability in the North Sea zooplankton off the Northum. berland coast: productivity of small copepods and analysis of trophic interactions. J. mar. biol. Ass. U.K. 68: $143-164$

Rudstam, L. G. (1988). Patterns of zooplanktivory in a coastal area of the northern Baltic proper. Ph.D. thesis, Univ. of Stockholm

Rudstam, L. G. (1989a). Exploring the seasonal dynamics of herring predation in the Baltic Sea: applications of a bioenergetic model of fish growth. Kieler Meeresforsch. Sonderh. 6: 312-322

Rudstam, L. G. (1989b). A bioenergetic model for Mysis growth and consumption applied to a Baltic population of Mysis mixta J. Plankton Res. 11: 971-983

Rudstam, L. G., Clay, C. S., Magnuson, J. J. (1987). Density and size estimates of cisco, Coregonus artedii using analysis of echo peak PDF from a single transducer sonar. Can. J. Fish. Aquat. Sci. 44: 811-821

Rudstam, L. G., Hansson, S., Larsson, U. (1986). Abundance, species composition and production of mysid shrimps in a coastal area of the northern Baltic proper. Ophelia, Suppl. 4: $225-238$

Rudstam, L. G., Hansson, S. (1990). On the ecology of Mysis mixta (Crustacea, Mysidacea) in a coastal area of the northern Baltic proper. Ann. Zool. Fenn. 27: 259-263

Rudstam, L. G., Danielsson, K., Hansson, S., Johansson, S. (1989a). Diel vertical migration and feeding patterns of Mysis mixta in the Baltic Sea. Mar. Biol. 101. 253-258

Rudstam, L. G., Lindem, T., Hansson, S. (1988). Density and in situ target strength of herring and sprat: a comparison between two methods of analyzing single-beam sonar data. Fish. Res. 6: 305-315

Rudstam, L. G., Palmén, L. E., Hansson, S., Hagström, O. (1989b). Acoustic fish abundance in a Baltic archipelago: comparison between results from echo integration and 
from analysis of echo peaks. Comm. Meet. int. Coun. Explor. Sea C.M.-ICES B:27

Rybock, J. T. (1978). Mysis relicta Lovén in Lake Tahoe vertical distribution and nocturnal predation. Ph.D. thesis, Univ. of California, Davis

Salemaa, H., Tyystjärvi-Muuronen, K., Aro, E. (1986). Life histories, distribution and abundance of Mysis mixta and Mysis relicta in the northern Baltic Sea. Ophelia Suppl. 4 239-247

Sandström, O. (1980). Selective feeding by Baltic herring Hydrobiologia 69: 199-207

Scavia, D., Lang, G. A., Kitchell, J. F. (1988). Dynamics of Lake Michigan plankton: a model evaluation of nutrient loading, competition, and predation. Can. J. Fish. Aquat. Sci. 45: $165-177$

Shvetsov, F. G., Starodub, M. L., Sidrevits, L. L. (1983). The daily feeding rhythm of Baltic sprat Sprattus sprattus balticus (Clupeidae). J. Ichthyol. 23: 99-105

Sissenwine, M. P. (1984). Why do fish populations vary? In: May, R. M. (ed.) Exploitation of marine communities. Springer-Verlag, Berlin, p. 57-94

Suthers, I. M., Frank, K. T. (1990) Zooplankton biomass gradient off south-western Nova Scotia: nearshore ctenophore

This article was submitted to the editor predation or hydrographic separation? J. Plankton Res. 12: $831-850$

Urho, L., Hildén, M. (1990). Distribution patterns of Baltic herring larvae, Clupea harengus L., in the coastal waters off Helsinki, Finland. J. Plankton Res. 12: 41-54

Viitasalo, M., Vuorinen, I., Ranta, E. (1990). Changes in crustacean mesozooplankton and some environmental parameters in the Archipelago Sea (Northern Baltic) in 1976-1984. Ophelia 31: 207-217

Vijverberg, J., Frank, T. H. (1976). The chemical composition and energy contents of copepods and cladocerans in relation to their size. Freshwat. Biol. 6, 333-345

Vuorinen, I. (1982). The effects of temperature on the rates of development of Eurytemora hirundoides (Nordquist) in laboratory culture. Ann. Zool. Fenn. 19: 129-134

Vuorinen, I., Ranta, E. (1987). Dynamics of marine mesozooplankton at Seili, northern Baltic Sea, in 1967-1975. Ophelia 28: 31-48

Wiktor, K., Szaniawska, A. (1989). The energy content in relation to the population dynamic of Mysis mixta (Crustacea). Kieler Meeresforsch. Sonderh. 6: 154-161

Wilmot, W., Toll, P., Kjerfve, B. (1985). Nutrient transports in a Swedish estuary. Estuar. coast. Shelf Sci. 21: 161-184

Manuscript first received: May 28, 1991

Revised version accepted: January 2, 1992 